\title{
Is a Universal Model of a 'Good' National Education System that brings Economic Returns Emerging?
}

\author{
Ekonomik Getirileri Artıran İyi Bir Ulusal Eğitim Sistemi \\ Evrensel Bir Model Olabilir mi?
}

\section{PhD. Mehmet Levent YILMAZ ${ }^{1}$ - MSc. Hüseyin Atakan KESKiN ${ }^{2}$}

Başvuru Tarihi: 18.03 .2020

Kabul Tarihi: 16.04.2020

Makale Türü: Derleme

\begin{abstract}
The consensus around the importance of educational quality on economic growth and societal development is more robust than ever. Major studies such as Hanushek \& Woessmann (2015; 2020) indicate that a nation's aggregate cognitive skills, measured with international mathematics and science assessments such as TIMMS, PIRLS, and PISA, is indicative of its educational quality, which is a vital component for economic growth. Such studies have also influenced the trajectory of international organizations so far as to include 'quality education' as one of the Sustainable Development Goals 2013 (United Nations, 2015). Therefore, by building on the studies asserting the importance of quality education and cognitive skills accumulation, we examine whether there is a universal model of a 'good' education system should look like is emerging. Based on observing the education systems of countries with a solid track record on international assessments aimed to measure cognitive skills, we argue that there seems to be various common themes, and also highly distinctive paths to success among highly renowned education systems.
\end{abstract}

Keywords: International Education, Educational Policy, Economic Development, Educational Economics, Human Capital, Educational Quality

Öz

Ĕ̆itim kalitesinin ekonomik büyüme ve toplumsal kalkınma üzerindeki önemi konusundaki fikir birliği her zamankinden daha sağlamdir. Hanushek \& Woessmann (2015; 2020) gibi önemli çalışmalar, bir ulusun TIMMS, PIRLS ve PISA gibi uluslararası matematik ve fen değerlendirmeleri ile ölçülen toplam bilişsel becerilerinin, ekonomik büyüme için hayati bir bileşen olduğunu gösteren eğitim kalitesinin bir göstergesi olduğunu göstermektedir. Bu tür çalışmalar, Sürdürülebilir Kalkınma Hedefleri 2013'ten biri olarak 'kaliteli ĕgitimi' içerecek

\footnotetext{
${ }^{1}$ Turkish National Police Academy, mehmetlevent.yilmaz@pa.edu.tr, ORCID: 0000-0001-5326-4198

${ }^{2}$ University of Oxford, St. Antony's College, atakan@fairopportunityproject.org, ORCID: 0000-0003-3171-7445
} 
şekilde uluslararası kuruluşların yörüngesini de etkilemiştir (United Nations, 2015). Bu nedenle, kaliteli ĕ̆itim ve bilişsel beceri birikiminin önemini ortaya koyan çalışmalara dayanarak, "iyi”" bir eğitim sisteminin ortaya çıkması gereken evrensel bir model olup olmadığını inceliyoruz. Bilişsel becerileri ölçmeyi amaçlayan uluslararası değerlendirmeler konusunda sağlam bir sicile sahip ülkelerin eğitim sistemlerini gözlemlemeye dayanarak, çeşitli ortak temalar ve aynı zamanda yüksek derecede tanınan eğitim sistemleri arasında başarıya oldukça belirgin yollar olduğunu iddia ediyoruz.

Anahtar Kelimeler: Uluslararası Eğitim, Eğitim Politikasl, Ekonomik Kalkınma, Ĕ̆itim Ekonomisi, Beşeri Sermaye, Eğitim Kalitesi

\section{Introduction}

The field of education has gained significant attention across various scientific disciplines with the advent of growth theories such as Solow's (1956) Growth Model, Mincer's (1974) Returns on Education, and Barro and Sala-i Martin's (1997; 2004) study on technological diffusion and growth. Later empirical findings suggested that the human capital of a nation is linked with the prosperity of a nation (Hanushek \& Woessmann, 2007; 2015), which turned that attention on education into new impetus of international organizations theorizing on what composes a 'good' national education system. The work of OECD, along with international student assessments such as PISA (OECD, 2016), TIMMS (Mullis, 2012), and PIRLS (Martin et al., 2017) in recent years, have created a vociferous debate on what constitutes a sound education system. Education now serves as a forefront in development indicators as being one of the 17 Sustainable Development Goals that the United Nations (2015) put forth with ambitious hopes of eradicating social and economic problems by 2030 .

"Notions of convergence and universalism surrounding "one best way" models are not new" (Rowley, 2018, p. 5), as studies claim countless 'one size fits all' models ranging from economic, political and educational governance (Fukuyama, 1992; Barro \& Sala-i Martin's, 1997). As cited in Rowley (2018), Fukuyama (1992) famously claimed the end of the human history, stating that liberal and democratic institutional governance models including political and educational models will triumph in the world; only later to admit that he underestimated the intricacies and the complexity of the world, and exaggerated his statement (Glancy, 2014). Education, a normative field itself (Besley, 2009), is a convoluted topic with subtleties, including sui generis needs of countries and ample cultures that make up societies. This paper, in conjunction with the works of others in education (see Fox, 1983; Grubb, 1999; Pratt, 2002), argues against the notion of 'universal emergence' of a proper national education system. On the other side of the spectrum, however, the paper acknowledges the effort, changes, and improvements carried out by international organizations (primarily OECD, UNICEF, and the World Bank) to nudge governing bodies towards quality education. Hence, the first section of the paper will elaborate on that global effort, followed by a section that delineates some of the reasons that support the rejection of such 'emergence,' and why it is not the future. The final section is a comparative analysis of the education systems of South Korea and Finland-two successful education systems, according to OECD (2016). It is important to note that this paper 
is not about assessing importance/relevance weights to determine which education system is the most successful; instead, it is an inquiry on the debate on the universal emergence of a sound education system.

\section{The Global Effort}

Much of the global effort to constellate a universal model of 'good' education has been predicated upon the idea of 'human capital theory,' which helps set the framework for education policies since the 1960s (Fitzsimons, 2017). Although can be traced back to Adam Smith's (1786) famous work of The Wealth of Nations, this theory is a further derivation of the basic neoclassical growth model, also known as the Solow Model (1956), which stated that economic growth is a function of physical capital - goods such as equipment, dams, machines, and buildings (Samuelson \& Nordhaus, 2010) — and population growth. Improved Solow models, such as Brumm (1991), claimed that economic growth that is not explained by physical capital and population growth is caused by human capital, which merely is the skills, knowledge, and the experience of people (OECD, 2009). The improved model suggested that human capital is the only variable that brings sustainable positive economic returns in the long-run (Brumm, 1991), and education fuels human capital (Denison, 1967).

Despite its intuitiveness, data used to test the validity of the human capital theory, however, yielded inconclusive results until the 2000s due to studies (see Mincer,1974; Barro \& Sala-iMartin, 2004) using educational attainment as the only measuring variable (Hanushek\& Woessmann, 2008). Later studies such as Hanushek and Woessmann (2007; 2008; 2015), asserted that a year of schooling could not be expected to produce analogous outcomes across the world because of differences in the quality of education provided by countries. They instead used cognitive skills, that being international student assessment scores such as PISA, TIMMS, and PIRLS, where students between the ages of 10-15 are tested for their numeracy, literacy, and real-life problem-solving skills (OECD, 2016), as a measure of human capital. Their findings revealed that cognitive skills could explain $78 \%$ of the variation in GDP per capita growth, while educational attainment did not provide any robust results. Their final suggestion of "a nation's prosperity is directly related to the skills of its population" (Hanushek\& Woessmann, 2015, p. 209), is one of the main contributors to the global effort of nudging countries to reform/redesign education systems. Ultimately, cognitive skills accumulation is a contributing factor towards untangling the economics growth paradoxes around the world and explaining substantial development differences amongst nations (Keskin \& Yilmaz, 2020).

The global effort to revamp education systems is based on the notion of teaching relevant skills for future employment (OECD, 2009); thus, driven by economic output concerns. Ever since its advent, PISA has helped bring global attention to education, and claim to have improved literacy and numeracy skills by narrowing the skills gap between countries (OECD, 2016). The OECD has been vocal for quality education, which factors such as teacher quality, equity, cognitive skills, and inclusiveness are some of the common themes around the education system they advocate for (OECD, 2012a). Other international organizations such as the United Nations (2015) have also made quality education a goal, and skills formation one of the targets of their Sustainable Development Goals 2030. Coincidentally, however, both the OECD and the United Nations also suggest that education systems cannot be replicated, and a one-size-fits-all or universal approach to education will not produce profound impacts on societies (Yiannouka\& Mouhyi, 2018; Rowley, 2018). These international organizations suggest that while it is 
essential to learn from high performing systems, countries should integrate their measures which accounts for different values, customs, culture, and immediate needs of the society into their education system (OECD, 2007). While these organizations advocate for more skills and quality-oriented approach in education, it is essential to note that education interventions that do not take unique socio-cultural, religious, and political aspects into account are likely to produce unintended results (Valiente, 2014). These unintended results may be exacerbated by a lack of understanding of different student needs, which vary significantly across different nations (Altinok\& Aydemir, 2017). On the basis thereof, while the universal emergence of the concepts education in terms of skills, and quality education - mostly driven by the human capital theory advocates - is acceptable; this is not to say that a universally accepted 'good' national education system is emerging, nor it would be a viable approach en route to increasing educational quality in the future.

\section{Issues Regarding One Size Fits All Models}

Valiente (2014) states that "the implementation of policy solutions from high-income countries in low- and middle-income is one of the most problematic international practices that have been inspired by modernization approaches to development" (p. 45). Although it is essential to analyze successful models, Keep (2018) points out that "the key is to think in terms of policy learning, not policy borrowing" (p. 2). On that premise, in their Strategy for Development Mandate, OECD (2012b) pledges to take a more holistic approach and constructively criticizes itself by stating:

The OECD also needs to learn from diverse growth and development experiences, reflect them in its analytical frameworks and policy advice, and better leverage its collective expertise and resources. There is no "one-size-fits-all" strategy. Development is a long-term process of economic and social transformation, and attention should be paid to development trajectories and policy sequencing rather than static comparisons (p. 4).

This statement denotes that the OECD should leave behind the so-called modernization approach to development, and assess more importance to the complexities behind countries development trajectories and needs. Robinson and Winthrop (2016) state that the first step in designing an education system goes through a deep understanding of local educational needs. They suggest that education systems should take a community-based approach given the needs of different stakeholders, in lieu of implementing systems that governments or universal models think those communities out to need. Keep (2018) also claims that one of the reasons Germany's Vocational Education and Training program performs outstandingly is due to the system belonging to stakeholders, rather than merely the government itself. These notions dovetail well with some of the criticism of Hanushek\& Woessmann's (2015) claims on the ineffectiveness of educational attainment on economic growth. Bretton (2011) argues that while international test scores may explain GDP per capita differences across nations, empirical data and models suggest that school enrollment plays a vital role in low and middle-income countries for their development. Therefore, while educational attainment might not serve as a determinant factor in economic growth trajectories of developed nations, it can be a crucial policy that may bring a profound impact to the people of low and middle-income countries.

In today's world, where global economic competition is at its highest, countries endeavor to thrive within specific markets by utilizing their competitive advantage (International Trade 
Forum, 2003). Given this, countries try to produce quality labor power within the specific sector of their focus. For instance, New York and London are ranked as the world's two financial capitals respectfully (Yeandle, Wardle \& Mainelli, 2018); and conjointly provides the world's top ten highest-ranked finance and accounting education (QS World, 2018). On the other side of the spectrum, Israel, with a population of 8.7 Million people (The World Bank, 2018,) produces the most innovation per-capita, and more start-up companies than countries such as, India, South Korea, Japan and the United Kingdom (Senor, Singer, \& Peres, 2011). To account for both the security threats of the region, and produce innovation, Israel made military service compulsory for all men and women, and created a unique system called 'Talpiot' in 1979 where soldiers are taught mathematics, physics, computer science, and other IT related courses while receiving military training (Gewirtz \& Zacks, 2016). Finally, the Netherlands "is a world leader in managing water (Netherlands Enterprise Agency, 2015, p. 1), and produces high-quality research in water management given their water level control issues dating back to the $800 \mathrm{~s}$ (Jong, 2004). Therefore, one justifiable inference would be that country needs, domestic politics, and various economic trajectories heavily influence the designs of education systems (Wales, Magee, \& Nicolai, 2016), which undermines the notion that a universal model of an excellent national education system will take place in the future.

Besides different development strategies and needs of countries, another concept regarding why the universal approach for a sound education system is not the future is differences in student needs, and human resources of a nation (Yiannouka \& Mouhyi, 2018). As cited in Yiannouka and Mouhyi (2018), research suggests that by targeting students with underprivileged financial backgrounds, and addressing their sui generis needs such as extended tutoring, and emphasis on of non-cognitive skills, urban charter schools in the US have had a significant effect on improving the achievements of those students (Abdulkadiroglu, Angrist, Dynarski, Kane, \& Pathak, 2011; Dobbie \& Fryer, 2011). This type of flexibility in schools is not only demanded by stakeholders in education, but also highlighted in studies as a significant suggestion given flexibility would help schools and education systems to adjust to the uncertainties of the future, and allow room further research and innovation in the policymaking in education (Robinson\& Winthrop, 2016). Regarding human resources of a country, governments are urged to design systems where resources are scaled and utilized effectively, rather than concentrating them on a few locations or institutions, to account for access and equity in education (Gottelmann-Duret \& Bahr, 2012). The significant variance in available resources across countries would indicate that an implementation of a universal model is far from achievable. Exempli gratia, Hanushek, Piopiunik, and Wiederhold (2018) empirical models (See Figure 1) suggest that the numeracy and literacy skills of Turkish and Chilean teachers are well below of Canadian employees with only vocational education. For both Turkish and Chilean education systems to hire teachers with similar qualities of the highly-celebrated Finnish teachers, they would need to pick from their top 3\% of the graduating cohort (Hanushek, Piopiunik\& Wiederhold, 2018). It seems unlikely that any government would devote their highest performing graduating cohort to merely teaching, given the amount of other critical jobs that are highly demanded, such as medical, engineering, legal, and technical professions that require a particular set of skills. Student needs and available human resources are, therefore, other factors that show how the future in education systems is directed towards local approaches rather than a universally accepted good national education model. 


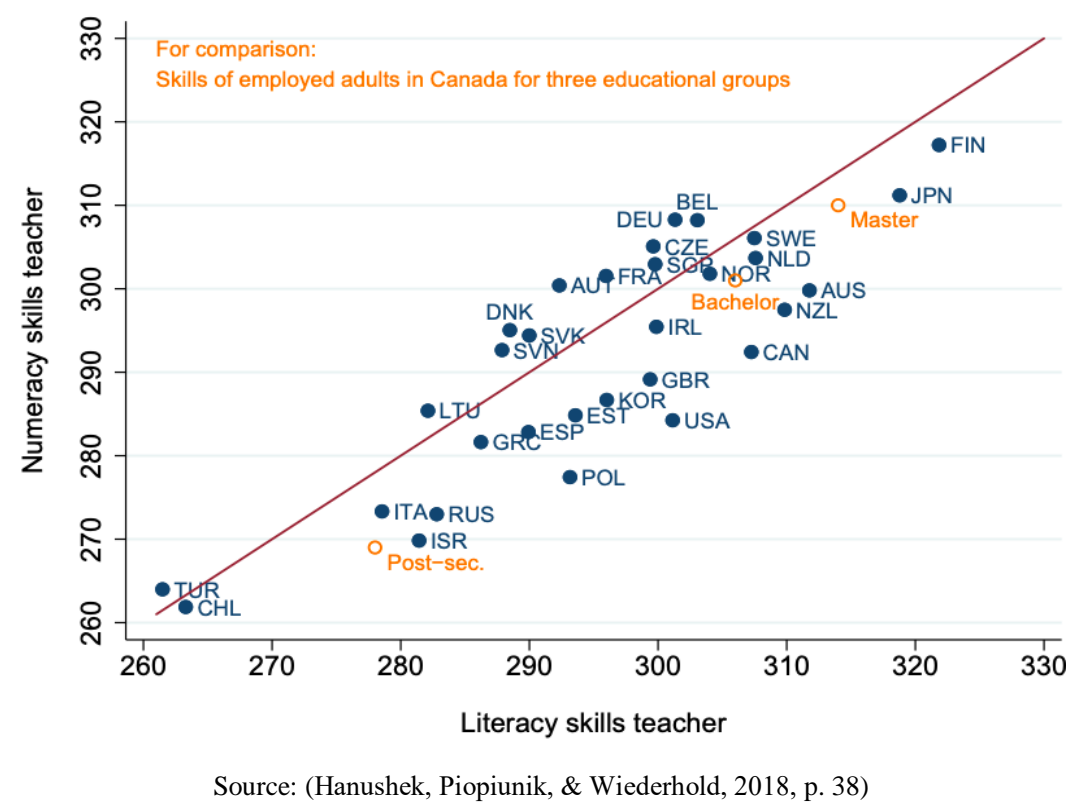

Figure 1. Teacher Cognitive Skills Compared to Canadian

Workers with Varying Education Levels

\section{Finland vs. South Korea}

Despite their poor performances fifty years ago, the education systems of Finland and South Korea, are now widely admired, given their stellar performance in international student assessments, and quality outcomes (OECD, 2016). While sharing common themes such as teacher selection and quality, both systems ultimately differ on the philosophies which their education systems are built upon (Choi, 2014). The Finnish system is based on extracurricular activities and intrinsic motivation by enforcing short school days due to their shared belief that learning also takes place outside of the classroom (Choi, 2014). Finnish students have "fewer hours of instruction than students in any other OECD country" (OECD, 2011, p. 121), and spend around 550 hours per annum in classroom - a strikingly low figure given countries such as the US spend more than 1080 hours in one school year (Sahlberg et al, 2015; OECD, 2011). Finnish schools are the centerpiece of communities and provide not only educational but also social amenities, ranging from health, dental, and psychological services (OECD, 2011), to help students discover and create an identity (Schleicher, 2012) (As cited in Choi, 2014). Finnish teachers have an absolute autonomy on their teaching as they are not bounded to teach the whole national curriculum, and textbook teaching methods/materials are left to teachers' discretion (OECD, 2011). Furthermore, teachers assign several responsibilities to students to increase their engagement and encourage them to take part in designing their learning activities and outcomes (Ministry for Foreign Affairs of Finland, 2017). As students age (grades 10-12), they are expected to maintain full control of their learning program, including courses and the pace which they wish to proceed within an academic year (OECD, 2011). In short, educational themes such as flexibility, individual choice, autonomy, and extracurricular activities stand out within the Finnish System. 
The South Korean education system, instead, is based on hard-work, endurance, and determinacy (Choi, 2014). Schleiher (2012) states that Korean culture is constituted around the notion of working hard and going through tough times today to ensure happiness and prosperity in the future. Educational achievement, influenced by their Confucian culture, is mainly assessed through rigorous examinations (Choi, 2014), which explains the reason behind South Korean students average more study hours (Bermeo, 2014), and sleep one hour less (Chosunilbo, 2009) in comparison to their age cohort in OECD countries. A typical student day may last as long as seventeen hours, as many students attend double school shifts, private tutoring, and self-studying sessions (Chakrabarti, 2013). Furthermore, South Korean students rank the lowest among 55 OECD countries and economies in the number of hours spent outside of school for activities, that being exercise, practicing sports, and surfing the internet (OECD, 2017). Even though built around important outcomes in conjunction with the Finnish system such as creative thinking, cognitive and non-cognitive skills, the curriculum South Korean schools follow is developed by the Ministry of Education, along with strictly enforced schedules such as the required one-hour career exploration per week for students in lower secondary schools (National Center on Education and the Economy, 2018). Despite being sharp contrast with one of the world's most feted education models, that being Finland's system, the South Korean education produces successful outcomes as the country is at $100 \%$ literacy, scores well-above the world average on the PISA exam, and has the highest completion rate of post-secondary education among OECD countries (Choi, 2014; OECD 2009, 2011, 2017; National Center on Education and the Economy, 2018).

\section{Conclusion}

This paper discussed the universal emergence of a 'good' national education and whether this emergence is the future. The first section conceded the argument that there are emerging common themes, rather than a system, in education such as encouraging cognitive skills accumulation led by international organizations, and the proponents of the human capital theory. Cognitive skills, measured with international science and mathematics assessments, are strong indicators of countries' per capita economic growth rates and development paradoxes around the world (Hanushek \& Woessmann, 2015; Keskin \& Yilmaz, 2020). Further sections, however, painted an elaborate picture of why a universal emergence of a single education system is not taking place. International organizations discourage the implementations of one size fits all approaches (OECD, 2012b) since merely copying successful educational systems is ubiquitously discouraged (Keep, 2018; Rowley, 2018; Valiente, 2014; Yiannouka\& Mouhyi, 2018). Besides, given the immense variety amongst concepts such as countries' development stages, sui generis needs, cultures, political designs, global economic ambitions, student needs, stakeholder expectations, and available human resources, national education systems are emerging to be more distinct than ever. Conclusively, Finland vs. South Korea's example resembles how two different systems, if interwoven with the culture and the expectations of their societies, can still produce exceptional educational outcomes.

Gottelmann-Duret and Bahr (2012) state that "education systems, like any other social system, are complex, composed of a multitude of interrelated factors that need to be 'put in concert' to achieve the system's goals. (p. 11). As per indicated in this paper, those goals differ across nations. Therefore, a 'good' national education system should be unique to the country and 
address the needs and the culture of its society. Therefore, a 'good' national education system should be unique to the country and address the needs and the culture of its society. Ultimately, one size fits all models appear to be disappearing, rather than emerging; and the future in sound national education systems does not seem to be singular and universal, but instead, plural and local.

\section{References}

Abdulkadiroğlu, A., Angrist, J., Dynarski, S., Kane, T., \& Pathak, P. (2011). Accountability and flexibility in public schools: evidence from bostons charters and pilots. The Quarterly Journal of Economics, 126, 699-748.

Altinok, N., \& Aydemir, A. (2017). Does one size fit all? The impact of cognitive skills on economic growth. Journal of Macroeconomics, 53, 176-190.

Barro, R., \& Sala-I-Martin, X. (1997). Technological diffusion, convergence, and growth. Journal of Economic Growth, 2(1), 1-26.

Barro, R. J., \& Sala-i-Martin, X. (2004). Economic growth. Cambridge (Mass.): MIT.

Bermeo, E. (2014). South Korea's successful education system: Lessons and policy implications for Peru. Korean Social Science Journal, 41(2), 135-151.

Besley, T. (2009). Assessing the quality of educational research in higher education: International perspectives. Rotterdam, Netherlands: Sense.

Breton, T. R. (2011). The quality vs. the quantity of schooling: What drives economic growth?, Economics of Education Review, 30(4), 765-73.

Brumm, H. J. (1996). The human capital augmented solow model revisited, Applied Economics Letters, 3(11), 711-14.

Chakrabarti, R. (2013, December 02). South Korea's schools: Long days, high results. Retrieved January 11, 2019, from https://www.bbc.co.uk/news/education-25187993

Choi, A. (2015, December 22). What the best education systems are doing right. Retrieved January 10, 2019, from https://ideas.ted.com/what-the-best-education-systems-are-doingright/

Chosunilbo. (2009, August 10). Korean youth study longest hours in OECD. Retrieved January 11, 2019, from http://english.chosun.com/site/data/html_dir/2009/08/10/ 2009081000200.html

Denison, E.F., (1967). Why growth rates differ; postwar experience in nine western countries. The World Bank, Washington: D.C. 
Dobbie, W., \& Fryer, R. G. (2011). Are high-quality schools enough to increase achievement among the poor? Evidence from the harlem childrens zone. American Economic Journal: Applied Economics, 3(3), 158-187.

Erdelen, W. (2008). One size does not fit all. A World of Science, 6(4), 1-24. Retrieved January 8, 2019, from http://www.unesco.org/science/document/AWOS_Vol6_4web.pdf

Fitzsimons P. (2017). Human capital theory and education. In: Peters M.A. (eds) Encyclopedia of educational philosophy and theory. Singapore: Springer.

Fox, D. (1983). Personal theories of teaching. Studies in Higher Education, 8, 151-163.

Fukuyama, F. (1992). The end of history and the last man. New York: Free.

Samuelson, P. A., \& Nordhaus, W. D. (2010). Economics. Boston: McGraw-Hill.

Gewirtz, J., \& Zacks, S. (2016). Israel's edge: The story of the IDF's most elite unit - Talpiot. Jerusalem: Gefen Publishing House.

Glancy, J. (2014, September 28). Francis Fukuyama: Yes, history's death was exaggerated. Retrieved January 6, 2019, from https:/www.thetimes.co.uk/article/francis-fukuyama-yeshistorys-death-was-exaggerated-059p817q9pm

Gottelmann-Duret, G., \& Bahr, K. (2012). Strengthening of education systems. International Institute for Educational Planning. Retrieved January 10, 2019, from http://www.iiep.unesco.org/sites/default/files/strenghtenning_of_education_systems__discussion_paper.pdf

Grubb, W. N. (1999). Honored but invisible an inside look at teaching in community colleges. New York: Routledge.

Hanushek, E., \& Woessmann, L. (2007). The role of education quality for economic growth. World Bank Policy Research Working Paper No. 4122. Available at SSRN: https://ssrn.com/abstract=960379

Hanushek, E., \& Woessmann, L. (2008). The role of cognitive skills in economic development. Journal of Economic Literature, 46(3), 607-668.

Hanushek, E., Woessmann, L., (2015). The knowledge capital of nations. education and the economics of growth. Cambridge: The MIT.

Hanushek, E. A., Piopiunik, M., \& Wiederhold, S. (2019). The value of smarter teachers international evidence on teacher cognitive skills and student performance. Journal of Human Resources, 54(4), 857-899. 
Hanushek, E., \& Woessmann, L. (2020). Education, knowledge capital, and economic growth. In The Economics of Education (pp. 171-182). Cambridge: Academic.

International Trade Forum. (2003). A country's competitive advantage. Retrieved January 9, 2019, from http://www.tradeforum.org/A-Countrys-Competitive-Advantage/

Jong, J. D. (2004). Challenges of climate change for water management in the Netherlands. Proceedings of the Water Environment Federation, 2004(15), 515-529.

Keep, E. (2018, September 20). What can we learn from technical education in Germany? Retrieved January 8, 2019, from https://feweek.co.uk/2018/09/21/what-can-we-learnfrom-vocational-training-in-germany/

Keskin, H. A., \& Yilmaz, M. L. (2020). The role of cognitive skills accumulation on educational quality and economic growth. Journal of Financial Researches and Studies, 12(22), 169179.

Martin, M. O., Mullis, I. V. S., \& Hooper, M. (2017). Methods and procedures in PIRLS 2016. Retrieved from Boston College, TIMSS \& PIRLS International Study Center.

Mincer, J. (1974). Schooling, experience, and earnings. New York: National Bureau of Economic Research.

Ministry for Foreign Affairs of Finland. (2017). FINFO - Education in Finland. Key to the nation's success. Otavamedia OMA, 1-31. Retrieved January 10, 2019.

Mullis, I. V. (2012). PIRLS 2011: International results in reading. Chestnut Hill, MA: TIMSS \& PIRLS International Study Center.

National Center on Education and the Economy. (2018). South Korea: Learning systems. Retrieved January 11, 2019, from http://ncee.org/what-we-do/center-on-internationaleducation-benchmarking/top-performing-countries/south-korea-overview/south-koreainstructional-systems/

Netherlands Enterprise Agency. (2015, December 07). Water. Retrieved January 10, 2019, from https://www.hollandtradeandinvest.com/key-sectors/water

OECD. (2007). Institutionalising sustainable development. OECD sustainable development studies. doi:10.1787/9789264019096-en

OECD. (2009). The value of people. OECD insights: Human capital, 22-37. doi:10.1787/9789264029095-3-en

OECD. (2011). Lessons from PISA for the United States, strong performers and successful reformers in education. OECD publishing, 227-256. doi:10.1787/9789264096660-12-en

OECD (2012a). Equity and quality in education: supporting disadvantaged students and schools, OECD publishing. http://dx.doi.org/10.1787/9789264130852-en 
OECD. (2012b). OECD strategy for development: Meeting of the council at ministerial level. OECD Paris, 1-12. Retrieved January 9, 2019.

OECD. (2016). PISA 2015 results (Volume II) policies and practices for successful schools. PISA, OECD publishing, Paris. doi:10.1787/9789264267510-en

OECD (2017)., PISA 2015 results (Volume III): Students' well-being, PISA., OECD publishing, Paris., https://doi.org/10.1787/9789264273856-en.

Pratt, D. (2002). Good teaching: One size fits all?. New Directions for Adult and Continuing Education, 2002(93), 5-15.

QS World. (2018, September 18). University rankings by subject 2018: Accounting \& finance. Retrieved from https://www.topuniversities.com/university-rankings/university-subjectrankings/2018/accounting-finance

Robinson, J. P., \& Winthrop, R. (2016). Millions learning: Scaling up quality education in developing countries. Center for Universal Education at Brookings, 1-160.

Rowley, C. (2018, December 24). Universal models do not sit easily in today's world. Retrieved January 6, 2019, from https://www.ft.com/content/8de3d754-02f7-11e9-99df$6183 \mathrm{~d} 3002 \mathrm{ee} 1$

Sahlberg, P., Ravitch, D., Hargreaves, A., \& Robinson, K. (2015). Finnish lessons 2.0 what can the world learn from educational change in Finland? New York: Teachers College.

Schleicher, A. (2012, July). Use data to build better schools. Retrieved January 10, 2019, from https://www.ted.com/talks/andreas_schleicher_use_data_to_build_better_schools

Senor, D., Singer, S., \& Peres, S. (2011). Start-up nation: The story of Israel's economic miracle. New York: Twelve.

Smith, A. (1786). An inquiry into the nature and causes of the wealth of nations (4th ed.). London: Printed for A. Strahan, and T. Cadell.

Solow, R. (1956). A contribution to the theory of economic growth. The Quarterly Journal of Economics, 70(1), 65-94.

The World Bank. (2018). World development indicators: Population [Data file]. Retrieved January 9, 2019, from https://data.worldbank.org/indicator/SP.POP.TOTL

United Nations. (2015). Transforming our world: The 2030 agenda for sustainable development. New York: UN.

United Nations Development Programme. (n.d.). Goal 4: Quality education. Retrieved December 31, 2018, from http://www.undp.org/content/undp/en/home/sustainabledevelopment-goals/goal-4-quality-education.html 
Valiente, O. (2014). The OECD skills strategy and the education agenda for development. International Journal of Educational Development, 39, 40-48.

Wales, J., Magee, A., \& Nicolai, S. (2016). How does political context shape education reforms and their success? Development Progress, 1-29. Retrieved January 10, 2019, from https://www.odi.org/sites/odi.org.uk/files/resource-documents/10808.pdf.

Yeandle, M., Wardle, M., \& Mainelli, M. (2018). The global financial centres index 24. Z/Yen Group and the China Development Institute, 1-55. Retrieved January 9, 2019.

Yiannouka, S., \& Mouhyi, Z. (2018, April 03). There is no one-size-fits-all school model: Developing a flexible and innovative education ecosystem. Retrieved January 8, 2019, from https://www.brookings.edu/blog/education-plus-development/2018/04/03/there-isno-one-size-fits-all-school-model-developing-a-flexible-and-innovative-educationecosystem/ 